\title{
New species of Acacia (Fabaceae, Mimosoideae) from tropical Australia
}

\author{
Mary D. Tindale and Phillip G. Kodela
}

\begin{abstract}
Tindale, Mary D. E Kodela, Phillip G. (National Herbarium of New South Wales, Royal Botanic Gardens, Mrs Macquaries Road, Sydney, NSW, Australia 2000) 1992. New species of Acacia (Fabaceae, Mimosoideae) from tropical Australia. Telopea 5(1): 53-66. Acacia arafurica, A. cataractae, A. delicatula, A. gracilenta and A. brockii from the north of Western Australia and the Top End of the Northern Territory are described and illustrated. Although some of these species occur in national parks, several have restricted distributions and should be considered especially in the management plans of Kakadu and Katherine Gorge National Parks.
\end{abstract}

\section{Introduction}

In the last decade or so the Top End and Kimberley regions of northern Australia have been more widely explored, resulting in the discovery of many new plant species. Several of these species are described here, so that they may be published prior to the forthcoming volume on Acacia in the Flora of Australia. Further collections are required to provide more information on taxonomic variation, distributions and ecology, since existing specimens are often in limited numbers or concentrated from more accessible areas. Recent findings of new taxa emphasise our limited current knowledge of these areas and the potential of future discoveries, which need to be considered in the management of National Parks and future planning for mining and tourism in the region.

The terminology of shapes in the descriptions of species is that defined by Lee (1948: 144). The diameter of flower-heads is only given as a guide, since it is often affected by the degree of pressure on the specimens during drying.

\section{Sect. Plurinerves (Benth.) Maiden \& Betche, Triangulares group}

\section{Acacia arafurica Tind. et Kodela, sp. nov.}

$\mathrm{Ab}$ Acacia sublanata Benth. differt phyllodiis crassioribus, 15-34 mm longis, 9-25 mm latis, inflorescentiis spicatis, 10-21 mm longis et pedunculis 2-5 mm longis.

TYPE: NORTHERN TERRITORY: Arnhem Land, Anguldili Creek, Murgenella Road, $11^{\circ} 45^{\prime} \mathrm{S}$, $133^{\circ} 10^{\prime} \mathrm{E}, \mathrm{R}$. Hinz 2, 25 May 1988; holo NSW 235594; iso BRI, CANB, DNA 32714, K, PERTH.

Rounded shrub to $3 \mathrm{~m}$ high. Branchlets terete, light brown or greyish brown, with a rusty or greyish hue resulting from the indumentum which is sparsely to densely pubescent to cobwebbed (the hairs hyaline, white and/or fawn, often curled, to 0.5 $\mathrm{mm}$ long, sometimes intermixed with red-brown papillose hairs); longitudinal ridges to $0.2 \mathrm{~mm}$ high. New shoots and young foliage reddish brown, resinous, cobwebbed. Phyllodes borne singly, subsessile, obliquely ovate-rhomboidal, asymmetrical, the lower margin almost straight to slightly curved, the upper margin abruptly curved to more 
than $90^{\circ}$ near pulvinus, then curved to apex, $1.5-3.4 \mathrm{~cm}$ long, $0.9-2.0(-2.5) \mathrm{cm}$ wide, flat, coriaceous, with a sparse to moderate cover of nonglandular, erect to subappressed hairs to $0.5(-0.7) \mathrm{mm}$ long (the hairs being similar to those on the branchlets), with (3-)4(-5) prominent longitudinal nerves, the minor nerves strongly reticulate, the margin thickened, often wavy when dry, the mucro minutely glanduliferous, acuminate, pungent, straight or oblique, 0.4-1.2 $\mathrm{mm}$ long; gland on the upper margin of the phyllode prominent, 1.6-2.5(-5.0) $\mathrm{mm}$ above the pulvinus, orbicular to elliptical, pale yellow, glabrous, $0.4-0.6 \mathrm{~mm}$ long, $0.3-0.5 \mathrm{~mm}$ wide, the orifice $<0.1 \mathrm{~mm}$ in diam.; pulvinus $0.5-1.2 \mathrm{~mm}$ long, cobwebbed-pubescent; stipules lanceolate to narrowovate, 1.5-2.1 mm long, glabrous or ciliolate with hairs to $0.4 \mathrm{~mm}$ long, striate with several nerves arising from the base, the apex acute to acuminate. Inflorescences spicate, borne singly or very rarely in pairs in the axils of the phyllodes, (10-)15-21 $\mathrm{mm}$ long, 4.0-5.5 mm wide, golden yellow; peduncles $2-5 \mathrm{~mm}$ long, moderately to densely pubescent; bracteoles composed of a narrow deltate lamina 0.6-1.1 mm long (the pointed apex longer than the young flower buds), with white hairs to $0.2 \mathrm{~mm}$ long on the margin, attached perpendicularly to a glabrous claw $0.2-0.6 \mathrm{~mm}$ long. Flowers 5merous; calyx membranous, $0.5-0.8(-1.1) \mathrm{mm}$ long, dissected for $1 / 3-1 / 2$ its total length, with faint midribs or keeled, the apices ciliolate with hairs to $0.2 \mathrm{~mm}$ long, otherwise glabrous; corolla 1.1-1.4(-1.8) mm long, resinous, dissected for 1/3-1/2 its length, the petals oblanceolate to narrow-obovate, glabrous, with a midrib, the apices thickened, incurved and often cucullate, darker than the rest of corolla; stamens with filaments to $3.6 \mathrm{~mm}$ long; ovary \pm oblong or narrow-obovate, red-brown, densely pubescent with white hairs to $0.25 \mathrm{~mm}$ long; style eccentric, to $2.7 \mathrm{~mm}$ long, often curled. Legumes linear, tapering gradually at both ends, \pm straight, constricted between the seeds, $6.5-10.5 \mathrm{~cm}$ long, (2.5-)4.0-4.5 mm wide, chartaceous, raised and longitudinally ribbed over seeds, clothed with appressed to erect, white, usually interwoven hairs to $0.5 \mathrm{~mm}$ long. Seeds 4-7 arranged longitudinally in the legume, (5.2-)6.0-7.0 $\mathrm{mm}$ long, 2.1-3.1 mm wide, black, glossy; pleurogram open, very slightly constricted towards the hilum; areole same colour as the rest of the seed, 3.8-5.3 mm long, $0.9-1.3$ $\mathrm{mm}$ wide; funicle cream-coloured, expanded into a turbinate aril, folded c. 3 times beneath the seed (only one specimen with fruit and seeds was examined). Flowering April-May, July. Fruiting September. Figure 1.

Distribution: Northern Territory: Darwin and Gulf District: Cobourg Peninsula southeast to Maningrida and Nabarlek. Figure 2.

HABITAT: In sandy soil on coastal river flats or near streams in the gorge country of the inland, sometimes in tall open forest. Often in swampy areas.

ETYMology: The specific epithet refers to the Arafura Sea which lies to the north of the region in which $A$. arafurica occurs.

Notes: R. Hinz uses the collecting number ' 2 ' for two separate specimens (including the specimen we have chosen as holotype, i.e. NSW 235594), possibly applying the number to indicate that they are the same species.

We are following Pedley's classification (1987) where Acacia sublanata has been referred to the Triangulares group in sect. Plurinerves, whereas Cowan \& Maslin (1990) placed $A$. sublanata with $A$. deltoidea Cunn. ex Don and its allies in sect. Plurinerves.

Acacia sublanata Benth., which occurs in the Top End of the Northern Territory, is allied to $A$. arafurica which has very similar flowers, but there are differences in the phyllodes and shape of inflorescences. In $A$. sublanata the inflorescences are globular or rarely shortly oblong (Pedley 1987: 319, Figure 2f) whereas in A. arafurica they are spicate (Figure 1a). In A. sublanata the minor reticulate nervation is less distinct and 
the areolae more acute, running \pm parallel with the main nerves, whereas the phyllodes of $A$. arafurica are larger and slightly thicker with a strong reticulate network between the main nerves (Figure $1 \mathrm{~b}$ ). The phyllodes of $A$. sublanata are mostly broadest at or above the middle (as stated by Cowan \& Maslin 1990). This is particularly noticeable in the specimens of $A$. sublanata with larger phyllodes, e.g. Maconochie 1519, but this is not always the case, e.g. Slee \& Craven 3078, whereas in $A$. arafurica they are broadest at or below the middle.

Pedley (1987) describes the legumes of $A$. sublanata (under Racosperma sublanatum (Benth.) Pedley) as 'glabrous'. In the material of $A$. sublanata that we have examined, e.g. v. Balgooy 1310 \& Byrnes, Lazarides \& Adams 171, Maloney NSW 126756, Must 771, Craven 6068 and Slee $\mathcal{E}$ Craven 3078, the legumes are pubescent, although in Specht 819 the fruit is subglabrous.

Specimens eXAmined: Northern Territory: Darwin and Gulf District: $12 \mathrm{~km} \mathrm{~N}$ Three Ways, Cobourg Peninsula, $11^{\circ} 13^{\prime} \mathrm{S}, 132^{\circ} 17^{\prime} \mathrm{E}$, Sivertsen 793, 29 May 1983 (DNA 24309, PERTH); near Tomkinson River, Maningrida, Brigden, Apr 1972 (BRI, DNA D4432); Nabarlek, $12^{\circ} 21^{\prime} \mathrm{S}, 1^{\circ} 3^{\circ} 20^{\prime} \mathrm{E}$, Hinz 2, 3 Apr 1988 (BRI, DNA 31436, MEL); Arnhem Land, Maningrida, $12^{\circ} 30^{\prime} \mathrm{S}, 134^{\circ} 17^{\prime} \mathrm{E}$, Coleman 31, 25 Sep 1988 (DNA 36642).

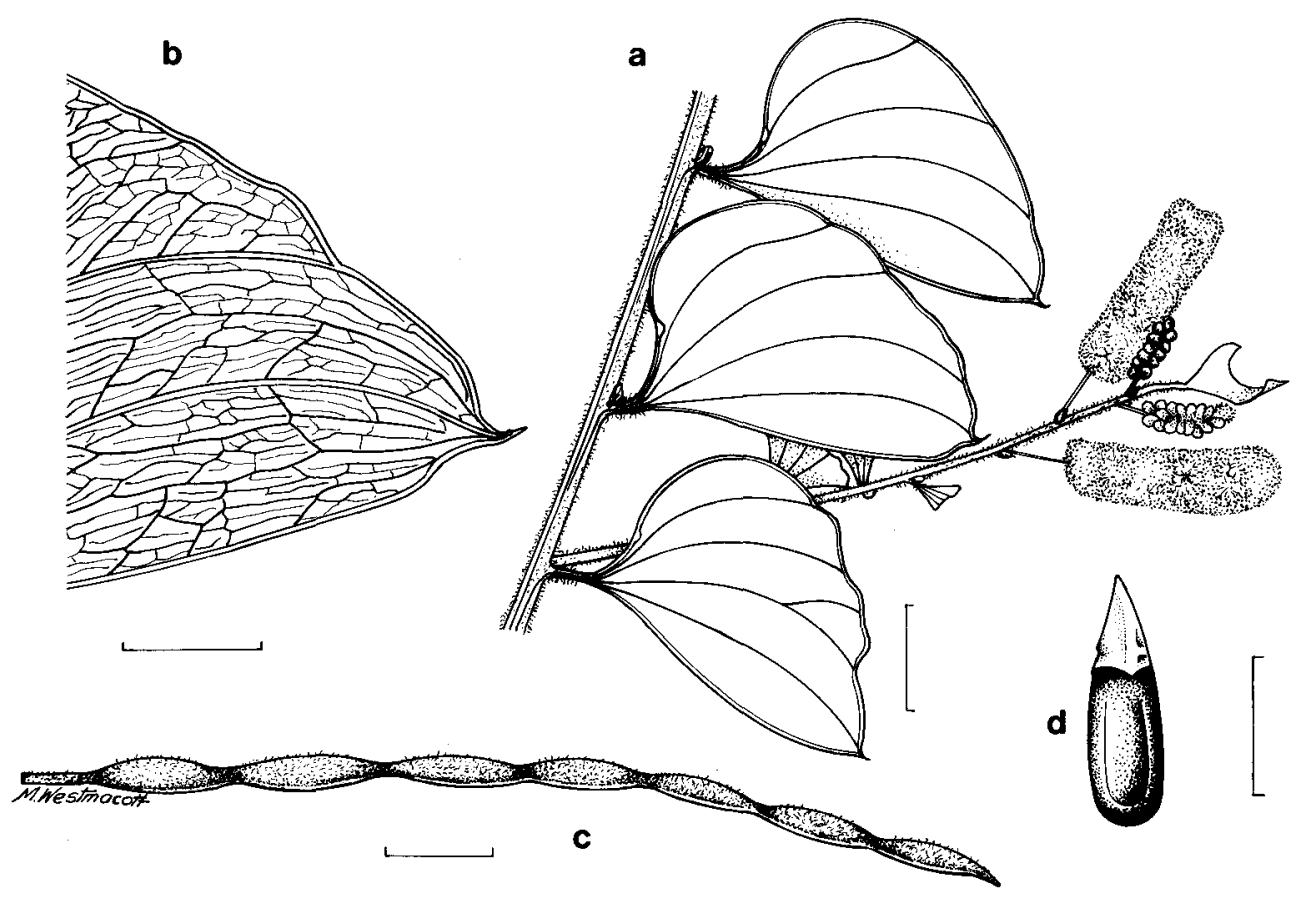

Figure 1. A. arafurica. a, habit study with spicate inflorescences; b, upper portion of phyllode; c, legume; d, seed (a,b, Sivertsen 793; c,d, Coleman 31). a,c, scale bar $=1 \mathrm{~cm}$; b,d, scale bar $=5 \mathrm{~mm}$. 


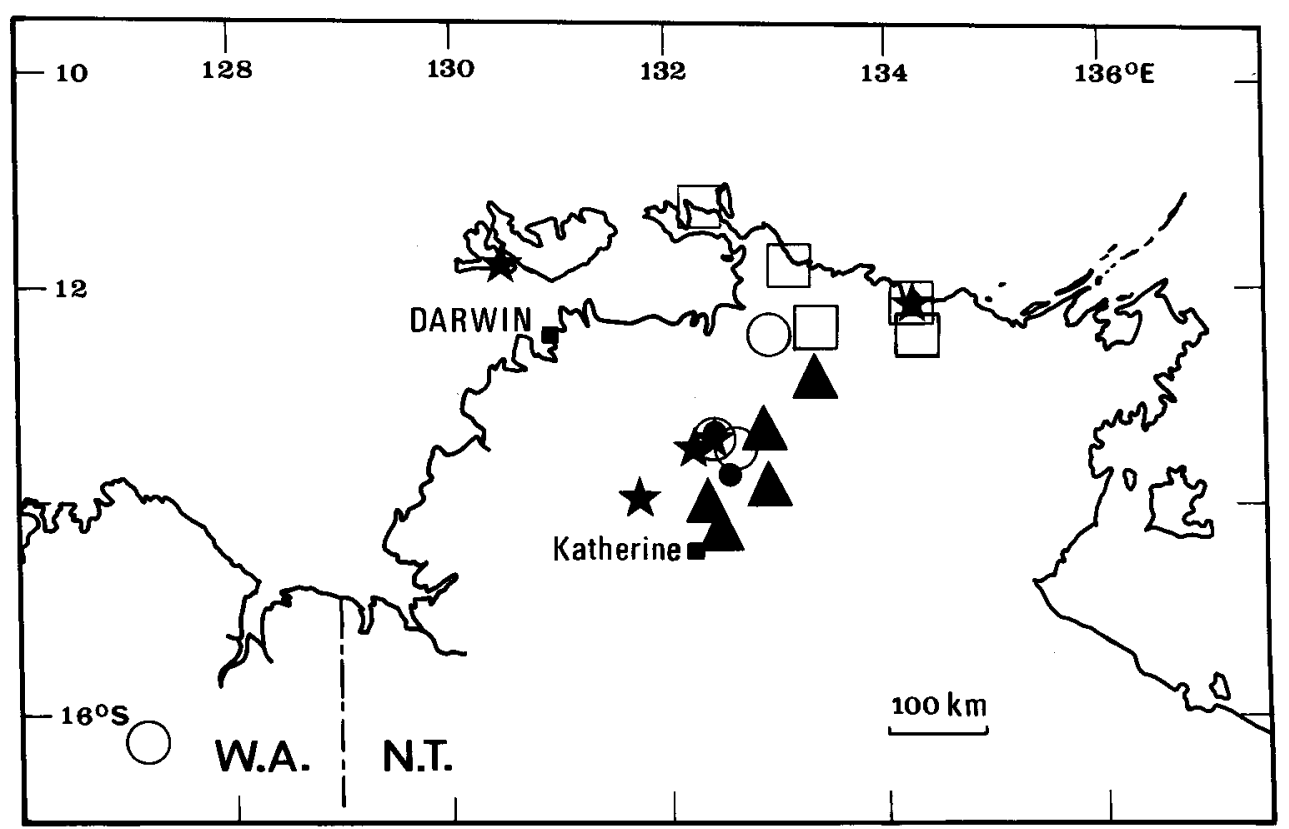

Figure 2. Distribution of Acacia arafurica $(\square)$, A. cataractae $(\star)$, A. delicatula (O), A. gracilenta $(\Delta)$ and A. brockii $(\bullet)$.

\section{Key to $A$. arafurica and $A$. sublanata}

1 Phyllodes (2.5-)5-13(-24) $\mathrm{mm}$ long, (1.5-)3-10(-14) $\mathrm{mm}$ wide, thinly coriaceous. Inflorescences mostly globular, $(4.5-) 6-7 \mathrm{~mm}$ in diam. or sometimes oblong. Peduncles (4-)7-15(-20) mm long

A. sublanata

1* Phyllodes 15-34 mm long, 9-20(-25) mm wide, coriaceous. Inflorescences spicate, (10-)15-21 mm long. Peduncles 2-5 mm long

A. arafurica

\section{Acacia stigmatophylla Cunn. ex Benth. group}

\section{Acacia cataractae Tind. et Kodela, sp. nov.}

Acacia cataractae: A. stigmatophyllae Cunn. ex Benth. affinis, a qua differt phyllodorum nervis 1-3 longitudinalibus margine inferiore plerumque confluentibus, calycibus $0.75-$ $1.0 \mathrm{~mm}$ longis, 2/3 partibus vel ad basin dissectis et petalis costa inconspicua.

TYPe: Northern Territory: Above U.D.P. Falls [Gunlom Falls, on Waterfall Creek], C.H. Gittins 2851, 3 May 1975; holo NSW 236250; iso BRI, CANB, DNA, K.

Shrub to $2 \mathrm{~m}$ high; bark brown, fibrous. Branchlets markedly angled to almost flattened towards apices, greenish brown to mid-brown, glabrous, with resinous, minutely 
crenulated ridges to $0.3(-0.5) \mathrm{mm}$ high. New shoots and young foliage yellowish green, resinous particularly towards apices. Phyllodes borne singly, oblanceolate to narrowoblanceolate or very narrow-elliptical, sometimes slightly asymmetrical, straight or very slightly curved, (3.5-)4.0-10.5 cm long, (6.5-)7.5-20.0(-23.0) $\mathrm{mm}$ wide, (3-)4-8 times as long as wide, grey-green, mid-green or dull dark green, flat, thinly coriaceous, glabrous, the margins nerve-like, crenulated with resin, with 3 prominent longitudinal nerves pale yellow, 2 of these reaching the base while the other usually confluent with the lower margin $0.5-1.7 \mathrm{~cm}$ from the pulvinus, sometimes with 4 subprominent longitudinal nerves, all other nerves faint with moderate anastomosing, 1-4 nerves per mm of phyllode width (longitudinal wrinkling produces a fine striated appearance); apex obtuse, often asymmetrically retuse or truncate, with a blunt, red-brown mucro 0.3-0.7 mm long, the gland minute; basal gland prominent, a \pm elliptical swelling on the upper margin just above the pulvinus, (0.8-)1.5-2.6 mm long, $0.4-1.2 \mathrm{~mm}$ wide, glabrous, with a \pm circular, slightly exserted, pale yellow lip c. $0.2 \mathrm{~mm}$ wide, the \pm circular orifice to $0.2 \mathrm{~mm}$ in diam.; pulvinus $(0.5-) 1.0-2.5(-3.5) \mathrm{mm}$ long, glabrous, often mealy; stipules deltate, $0.7-1.2 \mathrm{~mm}$ long, often somewhat mealy. Inflorescences spicate, borne singly or in twos or threes in the upper axils of the phyllodes (when in threes the spikes are often at different stages of development), (10-)14-50 $\mathrm{mm}$ long, (4.5-)5.5-7.5 mm wide, usually dense, yellow or bright to golden yellow, often densely mealy between flowers; buds obovate to very broad-obovate, very resinous; peduncles 4-12 mm long, glabrous, resinous. Flowers 5-merous; calyx membranous, $0.75-1.0 \mathrm{~mm}$ long, deeply cut to c. 2/3-3/4 its length, the sepals often \pm free, $0.1-0.2 \mathrm{~mm}$ wide, with a faint midrib, glabrous, the apex usually rounded; corolla 1.0 $1.5 \mathrm{~mm}$ long, dissected $1 / 3-1 / 2$ its length, glabrous, the petals elliptical to almost broad-elliptical or narrow-ovate, with a faint midrib, often mealy, often resinous, the apex acute; stamens with filaments to $3.2 \mathrm{~mm}$ long; ovary oblong to elliptical, granular, pubescent (especially towards the apex) or almost glabrous with a few minute hairs towards apex; style to $3.5 \mathrm{~mm}$ long. Legumes very narrow-oblanceolate (rarely linear), the base tapering gradually, straight or very slightly curved, $2.6-5.0 \mathrm{~cm}$ long, $4-7(-9.5)$ $\mathrm{mm}$ wide, straight-sided, woody, flat, slightly raised over the seeds, brown (greenish brown when young), glabrous, often scurfy, resinous (especially when young), the margins thickened, the surface with conspicuous diagonal nerves and some anastomosing, opening elastically from the apex, the apex \pm hooked. Seeds $7-13$ obliquely arranged in the legume, ellipsoid or oblongoid, sometimes \pm rhomboidal, (2.7-)3.0$4.0(-5.3) \mathrm{mm}$ long, $1.3-2.0 \mathrm{~mm}$ wide, brown, glossy; pleurogram open and slightly constricted towards the hilum; areole the same colour or slightly darker than rest of the seed, (1.8-)2.3-3.1(-4.2) $\mathrm{mm}$ long, 0.7-0.9 $\mathrm{mm}$ wide, often with a pale halo; funicle expanded into a cupular aril beneath the seed, the combined funicle-aril creamcoloured to tawny, narrowly turbinate. Flowering late December-January, March-July. Fruiting March-May. Figure 3a-e.

Distribution: Northern Territory: Darwin and Gulf District: From Bathurst Island and the Maningrida area, south to Umbrawarra Gorge $\left(13^{\circ} 58^{\prime} \mathrm{S}\right)$ near Pine Creek. Recorded in Kakadu National Park at Gunlom Falls, Graveside Gorge and Billiard Creek Road. Figure 2.

HABITAT: Usually found on sandy soil near streams in sandstone plateau-gorge country or on coastal plains, mostly in Eucalyptus woodland amongst rocks and boulders.

ETYMoLogy: The epithet refers to Waterfall Creek at Gunlom (U.D.P.) Falls, about 15 km NW of El Sharana, where this species is locally abundant.

Notes: It is a member of the A. stigmatophylla Cunn. ex Benth. group, which connects the Juliflorae with the Plurinerves (Tindale 1980). A. stigmatophylla is common in the Top End of the Northern Territory and in the Kimberley, Western Australia. 
A. cataractae has been confused with other tropical Australian species, viz. A. limbata F. Muell. (Kimberley, W.A., northern N.T. and north-western Queensland) and $A$. lazaridis Pedley (northern Queensland). The latter two species have larger legumes and seeds, longer peduncles (except in Adams 1138), more asymmetrical phyllodes and cupular calyces that are dissected for $1 / 4-1 / 3$ of their length. A. lazaridis usually has longer flowers than the other two species.

Selected SPECIMENS: Northern Territory: Darwin and Gulf District: Bathurst Island, $11^{\circ} 45^{\prime}$ S, $130^{\circ} 35^{\prime} \mathrm{E}$, Stevenson 159, 28 Dec 1975 (DNA); Maningrida area, $12^{\circ} 02^{\prime} \mathrm{S}, 134^{\circ} 17^{\prime} \mathrm{E}$, Clark 1306,26 Jul 1987 (BRI, DNA); Kakadu, Graveside Gorge 13¹9’'S, 132³3’E, Brock 190, 30 Dec 1986 (DNA); U.D.P. Falls, Sth Alligator R., Byrnes 1783, 4 Mar 1970 (BRI, DNA, K, NSW, NT); Kakadu National Park: U.D.P. Falls area: $0.7 \mathrm{~km}$ upstream from the top of falls, on Waterfall Creek, $13^{\circ} 25^{\prime}$ S, 132 $24^{\prime} \mathrm{E}$, Slee \& Craven 3045, 30 Apr 1990 (CANB, NSW); Waterfall Creek, Hancock 364, 26 May 1991 (CANB, DNA, K, NSW, PERTH); Kakadu National Park, Billiard Creek Road, $13^{\circ} 30^{\prime} \mathrm{S}, 132^{\circ} 14^{\prime} \mathrm{E}$, Menkhorst 297, 4 Mar 1989 (DNA); road to Umbrawarra Gorge, $13^{\circ} 56^{\prime} \mathrm{S}$, $131^{\circ} 45^{\prime} \mathrm{E}$, Brock 205, 13 Jan 1987 (DNA); Umbrawarra Gorge Rd, 135ㅇ's, 131 ${ }^{\circ} 40^{\prime} \mathrm{E}$, Brock 94,13 Mar 1986 (DNA).

\section{Acacia delicatula Tind. et Kodela, sp. nov.}

Acacia delicatula: A. subternatae F. Muell. affinis, sed phyllodiis linearibus-filiformibus, semiteretibus, $0.2-0.5 \mathrm{~mm}$ latis, capitulis $4.0-6.5 \mathrm{~mm}$ diametro, calycibus $0.6-1.0 \mathrm{~mm}$ longis, ad dimidiam vel plus dissectis, sepalorum apicibus plus minusve subulatis vel acuminatis et corollis $1.3-1.75 \mathrm{~mm}$ longis.

TYPE: NORTHERn TERrITORY: $2.7 \mathrm{~km} \mathrm{~W}$ of 'Rock Pools' (Bulbe gardar) along high track skirting the base of 'Geringbah' Escarpment [SW of Cahills Crossing], $12^{\circ} 28^{\prime} \mathrm{S}, 132^{\circ} 55^{\prime} \mathrm{E}$, C.F. Puttock \& J.T. Waterhouse, 24 July 1980; holo NSW 237163; iso DNA, K, UNSW 10162.

Erect to ascending, often spreading, resinous shrub to $1.5 \mathrm{~m}$ high, branching from the base; bark finely fissured. Branchlets \pm terete, striated, becoming markedly angular towards apices, light brown to brown, sometimes grey or greenish brown, glabrous, sometimes mealy, often resinous, the minutely crenulated ridges to $0.2 \mathrm{~mm}$ high. Phyllodes single or in clusters of 2-6, linear to filiform, semiterete, (4.5-)7-13(-18) mm long, (0.2-)0.3-0.4(-0.5) mm wide, straight or slightly curved, glabrous, nerves inconspicuous, the mucro acute to \pm aristate, often fawn-coloured, straight or oblique, to $0.5 \mathrm{~mm}$ long, bearing a minute gland. Capitula borne singly, $4.0-6.5 \mathrm{~mm}$ diam.; peduncles (5-)8-15(-18) mm long. Flowers 5-merous, 34-38 per capitulum; calyx 0.6-1.0 $\mathrm{mm}$ long, dissected for $1 / 2-3 / 4$ of its length, glabrous, the sepals $0.1-0.2 \mathrm{~mm}$ wide, usually with \pm subulate to acuminate apices; corolla $\mathrm{c}$. twice the length of the calyx, $1.3-1.75 \mathrm{~mm}$ long, dissected by $1 / 2$ or more of its length, the petals very narrowelliptical to narrow-lanceolate or narrow-oblanceolate, $0.2-0.4 \mathrm{~mm}$ wide, glabrous, with a distinct midrib, the apex thickened and often cucullate; stamens with filaments to $3 \mathrm{~mm}$ long; ovary glabrous, usually with a bulbous yellow cap on the summit. Legumes straight-sided or slightly indented between the seeds, very narrow-oblanceolate or sometimes \pm linear, basally tapered, $(2.0-) 3.0-4.0(-4.4) \mathrm{cm}$ long, $3-4 \mathrm{~mm}$ wide, flat, woody, glabrous, resinous (especially when young), opening elastically from the apex, obliquely to longitudinally nerved with minor anastomosing nerves, margins and partitions between seeds prominent, the apex hooked. Seeds 2-10, obliquely arranged in legume, ellipsoid or oblongoid (often irregularly shaped), (2.6-)3.0-3.9 mm long, (1.1-)1.3-2.1 mm wide, brown; pleurogram open, with a pale halo; areole slightly darker brown than rest of the seed; funicle-aril narrowly turbinate. Flowering January, March-April, July. Fruiting January, March-April, July-August. Figure $3 \mathrm{f}-\mathrm{j}$. 
Distribution: Occurs in north-western Western Australia and Kakadu National Park, Northern Territory. Figure 2.

HABITAT: Usually in shrubland or open eucalypt savannah on rocky or stony plateaux and hill slopes.

ETYMOLOGY: The epithet refers to the fine, narrow phyllodes of this species.

Notes: A. delicatula is closely allied to A. subternata F. Muell., which occurs in drier areas further south than the former (between c. $14^{\circ} 20^{\prime} S$ and $16^{\circ} 17^{\prime} S$ ) in the Northern Territory near Borroloola, Tanumbirini and Willeroo. Another closely allied species A. manipula Cowan \& Maslin ms., from the Kimberley area, Western Australia, differs from the former species in having less angular branchlets without prominent, minutely crenulated, resinous ridges and has longer phyllodes to $23 \mathrm{~mm}$ long. We have only seen one specimen of $A$. manipula ms., i.e. 9 miles [14.5 km] NE of Tablelands Homestead, Kimberleys, M. Lazarides 6398.

These species are members of the A. stigmatophylla group, which connects the Juliflorae with the Plurinerves (Tindale 1980). They differ from the other species listed in that their phyllodes are usually in groups of 2-6. In $A$. delicatula, $A$. subternata and $A$. manipula ms. there is often a bulbous, yellow or brown cap on top of the ovary.

Selected SPECIMENS: NoRTHERn TerRitory: Darwin and Gulf District: Kakadu, c. 2 km S East Alligator Ranger Stn, $12^{\circ} 25^{\prime}$ S, $132^{\circ} 59^{\prime} \mathrm{E}$, Noske, Aug 1987 (DNA 37225); near East Alligator River Ranger Station, Kakadu National Park, $12^{\circ} 29^{\prime} \mathrm{S}, 132^{\circ} 56^{\prime} \mathrm{E}$, Russell-Smith 936, 23 Jan 1984 (CANB, DNA, PERTH); Jabiluka Outlier, East of Ja Ja, [c. $12^{\circ} 30^{\prime} \mathrm{S}, 132^{\circ} 55^{\prime} \mathrm{E}$ ], Waterhouse \& Sanderson, 30

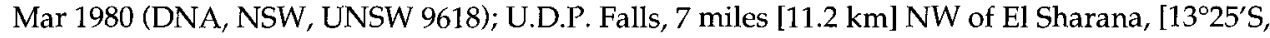
$132^{\circ} 25^{\prime} \mathrm{El}$, Martensz AE560, 24 Jan 1973 (BRI, CANB, DNA, NT); 13 miles [21 km] E of El

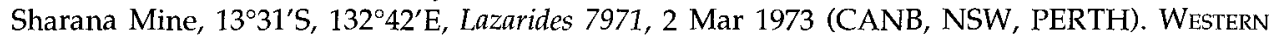
Australia: Fitzgerald: Gibb River - El Questro road, Karungi [Karunjie] Station turn-off, c. 130 $\mathrm{km} \mathrm{SW}$ of Wyndham, [16 $16^{\circ} \mathrm{S}, 127^{\circ} 12^{\prime} \mathrm{E}$ ], Beauglehole 51489, 28 May 1976 (BRI, PERTH); 50 metres E of turnoff to Pentecost Downs (Karunjie), Gibb River Road, Keith 225 \& Pellow, 7 Jul 1986 (NSW, SYD).

\section{Key to $A$. delicatula and $A$. cataractae and close allies}

1 Phyllodes usually in clusters of $2-6$, cultrate to filiform, or sometimes \pm narrowoblanceolate, 4-18 $\mathrm{mm}$ long, 0.2-0.85 $\mathrm{mm}$ wide, nerves inconspicuous.

2 Phyllodes linear to filiform, (0.2-)0.3-0.4(-0.5) mm wide. Capitula 4.0-6.5 mm in diam. Calyx $0.6-1.0 \mathrm{~mm}$ long, dissected by $1 / 2-3 / 4$, the sepals with \pm subulate or acuminate apices. Corolla $1.3-1.75 \mathrm{~mm}$ long, the petals with midrib only

A. delicatula

$2 *$ Phyllodes cultrate to linear or sometimes \pm narrow-oblanceolate, (0.4-)0.5-0.8 $(-0.85) \mathrm{mm}$ wide. Capitula $(5.0-) 6.5-8.5 \mathrm{~mm}$ in diam. Calyx (0.9-)1.1-1.2(-1.4) $\mathrm{mm}$ long, dissected c. $1 / 2$, the sepals \pm spathulate with broadly rounded apices. Corolla $1.7-2.3 \mathrm{~mm}$ long, the petals striated longitudinally .......... A. subternata

1* Phyllodes borne singly, oblanceolate to narrow-oblanceolate, or narrow-elliptical to very narrow-elliptical, $2.5-10.5 \mathrm{~cm}$ long, $6-23 \mathrm{~mm}$ wide, with several prominent longitudinal nerves.

3 Phyllodes with 1 of the 3 prominent longitudinal nerves usually confluent with the lower margin. Calyx $0.75-1.0 \mathrm{~mm}$ long, dissected by $2 / 3$ or to the base. Petals with faint midrib A. cataractae

$3^{*}$ Phyllodes with 3 prominent longitudinal nerves reaching the base. Calyx $0.5-0.75 \mathrm{~mm}$ long, cupular, dissected by $1 / 8-1 / 5$. Petals with prominent midrib A. stigmatophylla 

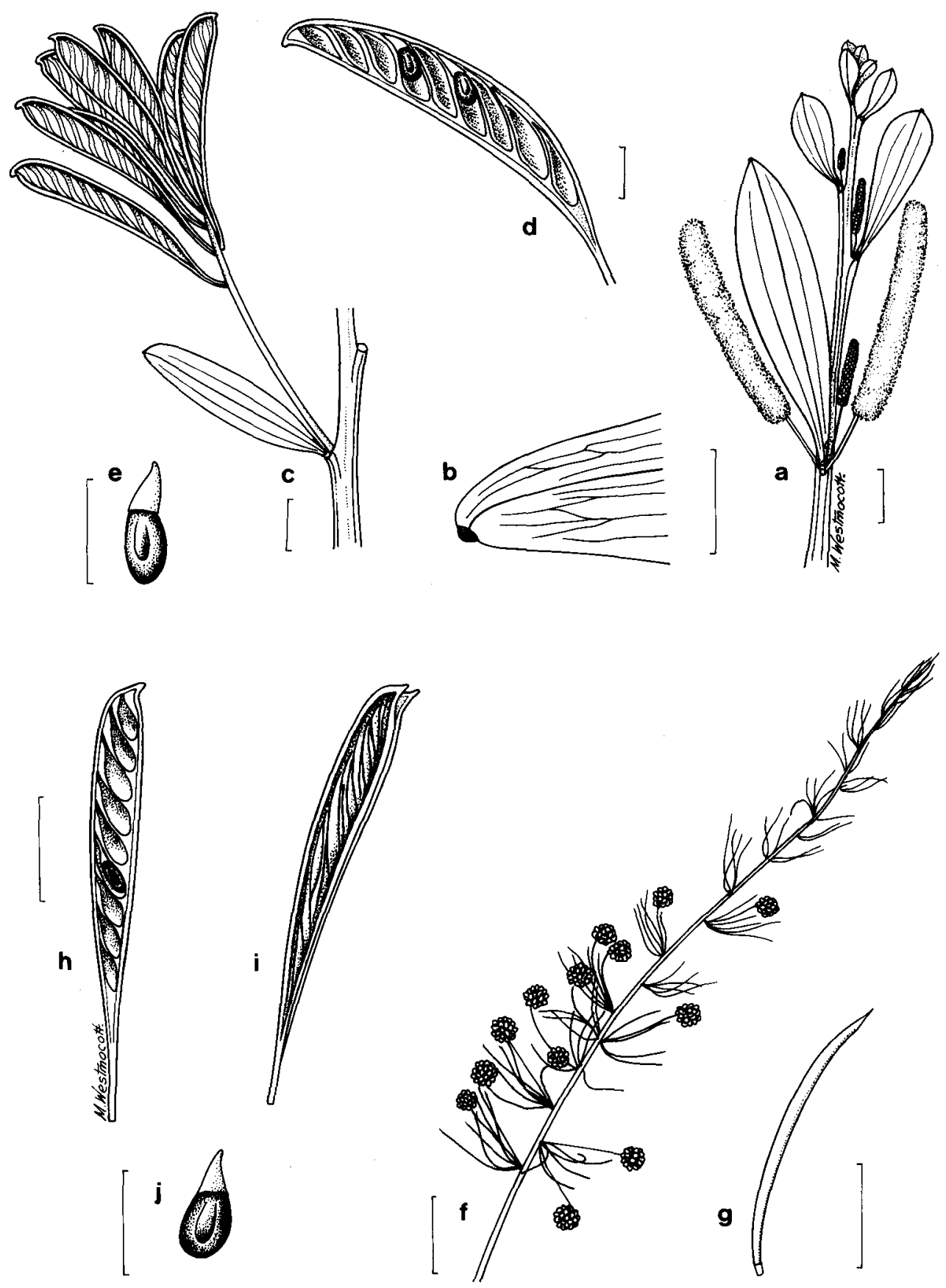

Figure 3. A cataractae $\mathbf{a}$, habit study with spicate inflorescences; $\mathbf{b}$, upper portion of phyllode; c, habit study with legumes; d, inside of legume; e, seed (a,c, Brock 94; b,d,e, Menkhorst 297). A. delicatula: $\mathrm{f}$, habit study with young capitula; $\mathbf{g}$, phyllode; $\mathbf{h}$, inside of legume; $\mathbf{i}$, outside of legume; $\mathrm{j}$, seed (f,g, Russell-Smith 936; $\mathrm{h}-\mathrm{j}$, Puttock \& Waterhouse UNSW 10162). a,c,f,h,i, scale bar $=1 \mathrm{~cm} ; \mathrm{b}, \mathrm{d}, \mathrm{e}, \mathrm{g}, \mathrm{j}$, scale bar $=5 \mathrm{~mm}$. 


\section{Sect. Juliflorae (Benth.) Maiden \& Betche}

\section{Acacia gracilenta Tind. et Kodela, sp. nov.}

Acacia gracilenta: A. linarioidi Benth. affinis, sed phyllodiis late dispositis, non rigide erectis, $2.7-10.2 \mathrm{~cm}$ longis et $1.4-6.5 \mathrm{~mm}$ latis, stipulis basi $0.3-0.6 \mathrm{~mm}$ latis, ramulis, pedunculis et inflorescentiarum axibus glabris vel fere glabris et ramulis minus angularibus statim diagnoscenda.

TYPE: NorThern TerRITORY: Arnhem Land, Upper East Alligator R., $12^{\circ} 50^{\prime} \mathrm{S}, 1^{\circ} 3^{\circ} 20^{\prime} \mathrm{E}$, J. Russell-Smith 5270 \& D. Lucas, 22 Apr 1988; holo DNA 36422; iso BRI, NSW 235962.

Shrub to $3 \mathrm{~m}$ high, often spindly, spreading from a single stem close to the ground (e.g. from c. $15 \mathrm{~cm}$ ); branches, branchlets and foliage resinous; bark greyish or light brown, \pm smooth. Branchlets terete, finely striate, pale green and usually mottled with light brown, glabrous or sometimes with sparsely scattered, subappressed, minute, hyaline hairs, lenticels prominent. New shoots and young foliage greenish brown to redbrown, the margins of the phyllodes with appressed transparent hairs. Phyllodes borne singly or occasionally in pairs, linear or sometimes \pm very narrow-elliptical, tapering gradually and equally from the centre or sometimes widest c. $2 / 3$ from the base, straight or slightly curved, (2.7-)4.0-6.0(-10.2) cm long, $1.4-5.0(-6.5) \mathrm{mm}$ wide, $7-30(-$ 45) times as long as wide, bright green, flat, herbaceous, glabrous or with appressed, opaque to transparent hairs to $0.6 \mathrm{~mm}$ long on the margin, the stomates prominent, the margins \pm nerve-like; main nerves longitudinal, arising from the base of the phyllode; midnerve prominent, usually with 1 semi-prominent nerve either side, (2-)3-6(-7) nerves per $1 \mathrm{~mm}$ of phyllode width, sparsely anastomosing; apices acute to obtuse, often slightly constricted, mucro straight to oblique, red-brown to orangebrown, $0.2-0.8 \mathrm{~mm}$ long, an inconspicuous gland to $0.2 \mathrm{~mm}$ in diam. just below the apex; an inconspicuous gland to $6 \mathrm{~mm}$ above the pulvinus, often slightly indented in the upper margin, broad-elliptical to elliptical or oblong, $0.3-0.6 \mathrm{~mm}$ long, $0.2-0.3$ $\mathrm{mm}$ wide, glabrous, the lip usually fawn, the orifice elliptical to slit-like, usually darker; pulvinus $0.5-1.8 \mathrm{~mm}$ long, wrinkles mostly transverse and often folded, brown or orange-brown, glabrous, often resinous; stipules 2 either side of pulvinus, 0.5-1.2 $\mathrm{mm}$ long, $0.3-0.6 \mathrm{~mm}$ wide at base, deltate, glabrous, with midnerve. Inflorescences spicate, borne singly in the axils of the upper phyllodes, 20-55 mm long, (3.5-)4.0-6.5 mm wide, c. 101-107 flowers per spike, golden; buds broad-ovate to very broad-ovate; peduncles 13-26 mm long, finely striate, glabrous, often resinous; bracteoles orangebrown, glabrous, usually resinous, the claw $0.15-0.3 \mathrm{~mm}$ long, the lamina \pm perpendicular to the claw, $0.25-0.55 \mathrm{~mm}$ long, \pm narrowly deltate, sometimes dentate. Flowers 5 -merous; caly $x$ membranous, inconspicuous, the sepals almost free, cultrate to linear, $0.2-0.3(-0.4) \mathrm{mm}$ long, the apices obtuse or \pm spathulate; corolla $(0.9-) 1.0-1.3(-1.5) \mathrm{mm}$ long, dissected for 1/3-1/2 of the total length (often to the base in older flowers), the petals elliptical to broad-elliptical or narrow-obovate, $0.5-0.7 \mathrm{~mm}$ wide, with a distinct midrib, glabrous, often resinous, the apex thickened, often incurved and sometimes cucullate; stamens with filaments to $2.8 \mathrm{~mm}$ long; ovary oblong-elliptical, subsessile, brown, glabrous or sometimes with a few scattered, \pm appressed, hyaline hairs to $0.15 \mathrm{~mm}$ long; style \pm eccentric, $1.5-3.0 \mathrm{~mm}$ long. Legumes linear, usually curved, constricted between the seeds, coriaceous, (2-)4-9(-12) cm long, $2.5-4.0 \mathrm{~mm}$ wide, brown; margins paler, \pm prominent; surface \pm flat, slightly raised over the seeds, with several longitudinal nerves and minor anastomosing nerves, glabrous, usually resinous. Seeds (1-)6-11 arranged longitudinally in the legume, ellipsoid to narrow-ellipsoid, 3.5-4.3(-5.7) $\mathrm{mm}$ long, 1.6-1.9(-2.7) $\mathrm{mm}$ wide, very dark brown or red-black to black; pleurogram closed, a very narrow groove separating the areole from the rest of 
the seed, often with a shallow trough around the pleurogram; areole $1.6-2.0(-2.6) \mathrm{mm}$ long, $0.4-0.55(-1.0) \mathrm{mm}$ wide, flat or slightly depressed, \pm the same colour as the rest of the seed, sometimes less shiny; funicle cream-coloured, filiform, expanded into a cap-like aril, folded c. 5 times beneath the seed. Flowering and fruiting April-May, August. Figure 4.

Distribution: Northern Territory: Darwin \& Gulf District: Arnhem Land, Kakadu National Park and Katherine Gorge National Park. Figure 2.

Навітат: Occurs in sandy soils on dissected sandstone plateaux and in gorges; often on slopes near rivers and creeks, growing amongst shrubs and sometimes with spinifex in open eucalypt woodland or Allosyncarpia forest.

ETYMOLOG: The epithet refers to the rather graceful canopy of this member of sect. Juliflorae.

Notes: A. gracillima Tind., which is restricted to the Kimberley region of W.A. especially in the King Leopold Ranges, is frequently confused with $A$. linarioides, which is a member of the $A$. lysiophloia group (Tindale 1978). It can be easily distinguished from $A$. gracilenta by its dark red, very curly bark, i.e. 'Minni Ritchi', and long hairs on the legumes. A. linarioides Benth. (occurring in the N.T. north of $17^{\circ} \mathrm{S}$ and on islands in the Gulf of Carpentaria) has slightly more angled branchlets and is more hairy than $A$. gracilenta.

SPECIMENS EXAMINED: NorThern Territory: Darwin \& Gulf District: Twin Falls, Jim Jim Falls area, $13^{\circ} 18^{\prime} \mathrm{S}, 132^{\circ} 52^{\prime} \mathrm{E}$, Fox 559, 17 Aug 1974 (DNA 11803); $20 \mathrm{~km}$ south-east of Twin Falls, $13^{\circ} 27^{\prime} \mathrm{S}$, $132^{\circ} 54^{\prime} \mathrm{E}$, Lazarides 8962, 24 May 1980 (BRI, CANB, NSW 235981); Kakadu National Park, upper

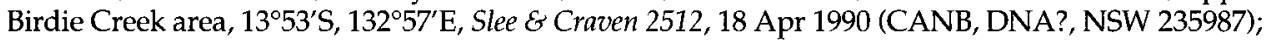
Second Spring, Seventeen Mile Valley, Katherine [Gorge] National Park, $14^{\circ} 06^{\prime} \mathrm{S}, 132^{\circ} 24^{\prime} \mathrm{E}$, Tindale 6038 \& Dunlop, 8 July 1979 (CANB, K, NSW 235964, UNSW); Katherine Gorge National Park, $14^{\circ} 18^{\prime} \mathrm{S}, 132^{\circ} 28^{\prime} \mathrm{E}$, King 117, 2 June 1982 (DNA 23304).

\section{Key to $A$. gracilenta and A. linarioides}

1 Phyllodes \pm well-spaced, not stiffly erect, (2.7-)4-6(-10.2) cm long, 1.4-5(-6.5) mm wide. Stipules $0.3-0.6 \mathrm{~mm}$ wide at base. Branchlets, peduncles and axes of the inflorescences glabrous or almost so. Legumes $2.5-4.0 \mathrm{~mm}$ wide A. gracilenta

1* Phyllodes numerous, usually crowded, rather stiffly erect, $1-4.3 \mathrm{~cm}$ long, $0.4-2 \mathrm{~mm}$ wide. Stipules $0.1-0.2(-0.3) \mathrm{mm}$ wide at base. Branchlets, peduncles and axes of the inflorescences usually sparsely to densely clothed with hairs to $0.7 \mathrm{~mm}$ long. Legumes $1.0-3.5 \mathrm{~mm}$ wide A. linarioides

\section{Acacia brockii Tind. et Kodela, sp. nov.}

Arbor gracilis, ad $5 \mathrm{~m}$ altam, phyllodiis argenteogriseis. Ramuli lenticellis, pilis albis plus minusve vestitis. Phyllodia juvenilia resinosa. Phyllodia linearia, recta vel parum curvata, $8.5-25.6 \mathrm{~cm}$ longa, $1.4-2.75 \mathrm{~mm}$ lata, plana, plus minusve rigida, pilis albis, caducis, appressis; nervis principalibus longitudinalibus, non anastomosantibus; mucrone apicali obliquo, 0.9-2.5 mm longo, glandula modo supra pulvinum disposita. Inflorescentiae spicatae, singulares vel binatim e phyllodiorum axillis ortae, 23-43 $\mathrm{mm}$ longae, 3.5-4.5 mm latae, flavidae. Bracteolae florum ciliatae, alabastra superantiae apicibus acuminatis vel subulatis. Flores quinquemeri; calyx $0.8-0.9 \mathrm{~mm}$ longus, 

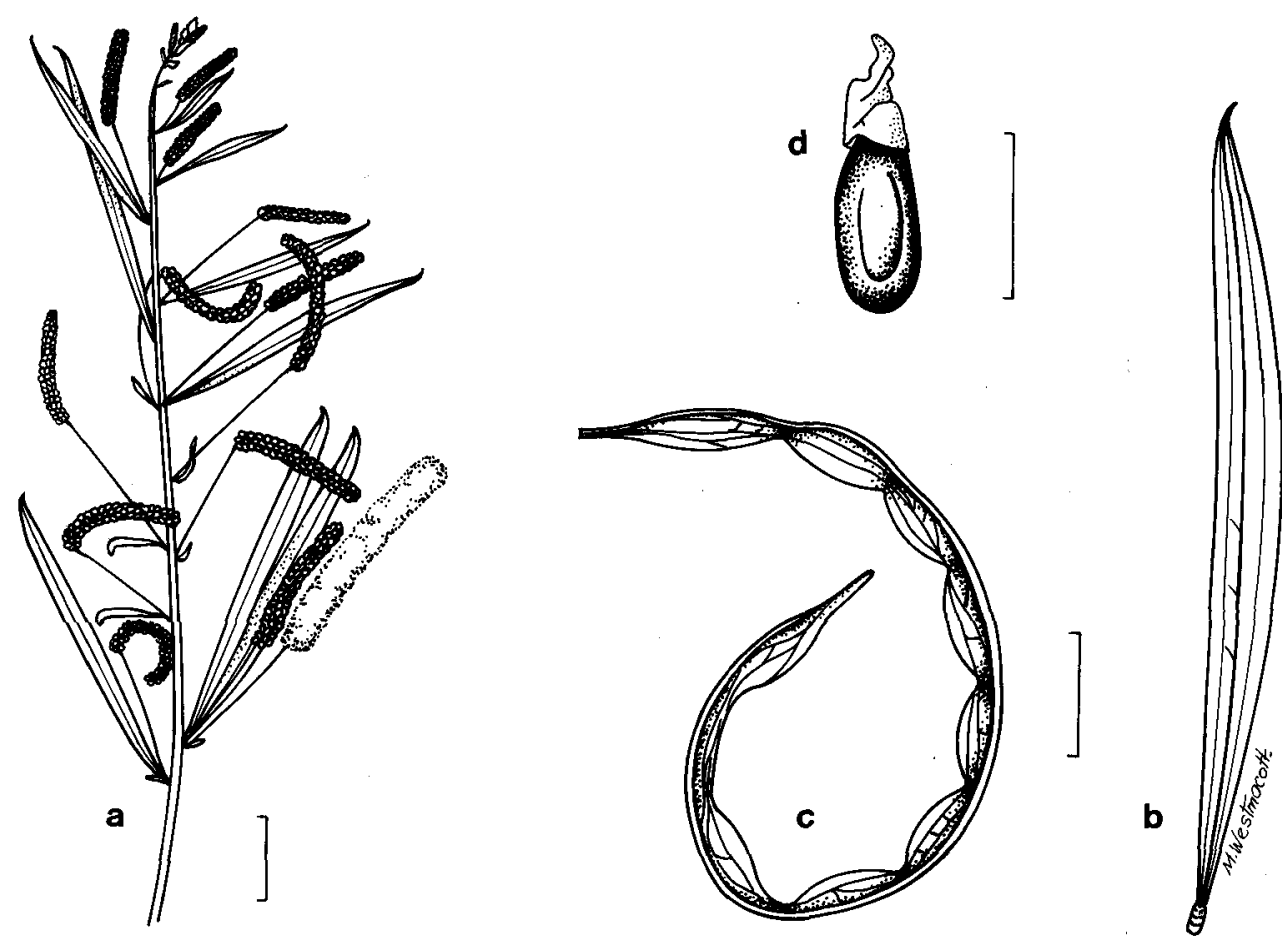

Figure 4. A. gracilenta. a, habit study with spicate inflorescences; $\mathbf{b}$, phyllode; $\mathbf{c}$, legume; $\mathbf{d}$, seed (a, Tindale 6038 \& Dunlop; b, Slee \& Craven 2512; c,d, King 117). a,b,c, scale bar $=1 \mathrm{~cm}$; d, scale bar $=5 \mathrm{~mm}$.

pilis tenuibus argenteis vestiti; corolla 1.2-1.5 mm longa. Legumina linearia, recta vel parum curvata, raro indentata, 8.0-11.7 $\mathrm{cm}$ longa, 4.7-6.0 $\mathrm{mm}$ lata, papyracea, pallide brunnea, glabra. Semina 9-11, longitudinalia, 3.6-4.7 mm longa, 2.3-2.9 mm lata, brunnea; areolus brunneus; funiculus hinnuleus, ter plicatus arillum cupulum faciens, secus seminis latum unum prolongatus.

TYPE: NORTHERN TERRITORY: Kakadu National Park: $18.5 \mathrm{~km} \mathrm{~S}$ of Gimbat HS [Homestead] (below E edge of Marawal Plateau), $13^{\circ} 44^{\prime} \mathrm{S}, 132^{\circ} 36^{\prime} \mathrm{E}$, A.V. Slee \& L.A. Craven 2694, 21 Apr 1990; holo NSW 236231; iso BRI, CANB, DNA, K, L, MEL, US.

Slender tree to $5 \mathrm{~m}$ high appearing silver-grey due to indumentum of the foliage, bark tight, smooth, dark grey. Branchlets terete, becoming angular towards the apices, redbrown, with lenticels, sparsely to densely (more dense towards apices) covered with appressed to semi-erect whitish hairs, with 5-7 prominent, longitudinal ridges to 0.2 $\mathrm{mm}$ high. New shoots and young foliage resinous, reddish brown, densely pubescient with appressed hairs. Phyllodes borne singly, linear, tapering gradually to the base and apex, straight or slightly curved, (8.5-)11.0-25.6 cm long, 1.4-2.75 mm wide, 45113 times as long as wide, flat, \pm rigid, covered with appressed, caducous, silvery hairs to $0.6(-1.2) \mathrm{mm}$ long (mixed with fawn hairs on younger phyllodes), older phyllodes bright green and only partly covered with hairs or almost glabrous; main nerves longitudinal, arising from the base of the phyllode, the midnerve usually slightly more prominent, 5-8 nerves per $\mathrm{mm}$ of phyllode width, not anastomosing; 
mucro reddish black or orange-brown, oblique or sometimes straight, $0.9-3.0 \mathrm{~mm}$ long, often resinous, glanduliferous, the gland cobwebbed to \pm glabrous, $0.2-0.4(-0.6)$ $\mathrm{mm}$ long, $0.2-0.3(-0.4) \mathrm{mm}$ wide; gland just above the pulvinus glabrous or covered with appressed hairs, \pm circular to elliptical, $(0.3-) 0.5-0.8 \mathrm{~mm}$ long, $0.3-0.55 \mathrm{~mm}$ wide, the orifice circular to elliptical, $0.05-0.2 \mathrm{~mm}$ in diam.; pulvinus $1.4-2.9(-3.5) \mathrm{mm}$ long, wrinkles mostly transverse, pale yellow to pale brown, glabrous or sparsely to densely hairy; stipules $0.7-0.9 \mathrm{~mm}$ long, deltate, ciliolate. Inflorescences spicate, borne singly or in pairs in the axils of the phyllodes, (15-)20-43 mm long, 3.5-4.0(-4.5) mm wide, pale yellow; immature spikes with bracteoles extending beyond the silvery white, hairy flower-buds; peduncles 2-3 mm long, densely pubescent with whitish and fawn to brown hairs; bracteoles brown or orange-brown, the claw $0.3-0.6 \mathrm{~mm}$ long, pubescent, the lamina perpendicular to the claw, narrowly deltate with an acuminate to \pm subulate apex, ribbed, $1.0-1.7 \mathrm{~mm}$ long, with silvery white hairs to $0.3 \mathrm{~mm}$ long on the paler margins and usually covering the outer surface. Flowers 5-merous; calyx cupular, membranous, pale cream to fawn, $0.8-0.9 \mathrm{~mm}$ long, dissected for $1 / 5-1 / 3$ of its total length, ciliolate, covered with silky hairs to $0.2 \mathrm{~mm}$ long, markedly incurved at the apices, sepals adaxially keeled; corolla 1.2-1.5 mm long, dissected for 2/5-1/2 of its length into 5 narrow-oblanceolate to narrow-obovate or narrow-elliptical, glabrous petals; stamens with filaments to $2.5 \mathrm{~mm}$ long; ovary subsessile, \pm oblong, sparsely to moderately pubescent; style borne centrally on the ovary apex, to c. $2 \mathrm{~mm}$ long. Legumes linear, straight or very slightly curved, straight-sided or sometimes very slightly constricted between the seeds, $8.0-11.7 \mathrm{~cm}$ long, $4.7-6.0 \mathrm{~mm}$ wide, papyraceous, pale brown, flat, convex over the seeds, glabrous (only a few mature legumes and no developing legumes were examined). Seeds 9-11 longitudinal in the legume, oblongoid to broad-oblongoid or ellipsoid to broad-ellipsoid, 3.6-4.7 mm long, 2.3$2.9 \mathrm{~mm}$ wide, mid-brown, smooth, glossy; pleurogram open and slightly constricted towards the hilum; areole same colour as the rest of the seed, $2-3 \mathrm{~mm}$ long, $0.7-1.1$ $\mathrm{mm}$ wide, with a pale halo $0.15-0.25 \mathrm{~mm}$ wide; funicle fawn, filiform, expanded into a cap-like aril, folded 3 times beneath the seed and prolonged along one side. Flowering April-May, July. Fruiting May, October. Figure 5.

Distribution: Northern Territory: Darwin and Gulf District: south-western part of Kakadu National Park. Figure 2.

Habitat: Occurs in dry Asteromyrtus heathland on crumbly red kaolinitic soil and in sandstone gorges on deep sands; often near permanent or seasonal streams.

EтYмоLogY: The specific epithet honours Mr John Brock (1951-), who collected the first specimens of this new species. His extensive collections throughout the Top End have extended our knowledge of its flora as well as raised an awareness of the needs for conservation.

Notes: A. brockii is a distinctive member of sect. Juliflorae, being characterised by the caducous, appressed hairs on the phyllodes, the ciliate ribbed bracteoles with acuminate to subulate apices extending beyond the flower-buds, the pale yellow spikes and by fine, long, silvery hairs on the calyces.

SPECIMENS EXAMINED: NoRTHERn TerRITORY: Darwin and Gulf District: Barramundie Gorge, $13^{\circ} 19^{\prime} \mathrm{S}$, $132^{\circ} 26^{\prime} \mathrm{E}$, Brock, 16 May 1984 (DNA 25091); Barramundie Gorge, 1320' $\mathrm{S}, 1^{\circ} 2^{\circ} 25^{\prime} \mathrm{E}$, Brock 100, 11 Jul 1986 (DNA 28309), ditto, Brock 109, 8 Oct 1983 (DNA 28310); Kakadu National Park, $13^{\circ} 44^{\prime}$ 'S, 132 37'E, Dunlop 8543 \& Munns, 21 Apr 1990 (BRI, CANB, DNA, MEL, MO, NSW 236608, PERTH, UC). 


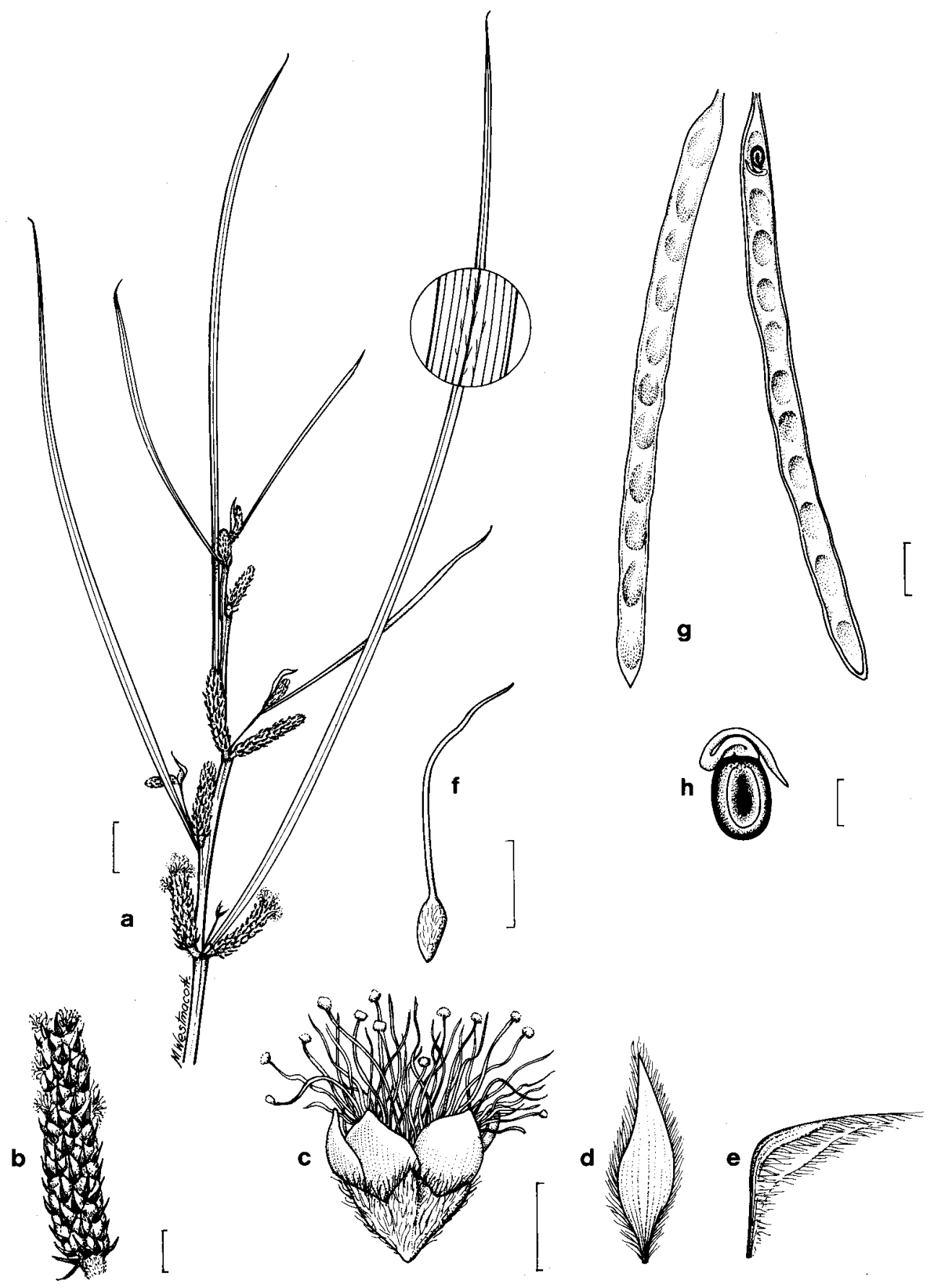

Figure 5. A. brockii. a, habit study with young inflorescences and inset showing nerves; $b$, young inflorescence; c, flower; d,e, bracteoles; f, gynoecium; g, legume; h, seed (a,b, Dunlop $8543 \mathcal{E}$ Munns; c-f, Brock 100; g,h, Brock 109). a,g, scale bar = $1 \mathrm{~cm}$; b,h, scale bar $=2 \mathrm{~mm}$; c,d,e,f, scale bar $=1 \mathrm{~mm}$. 


\section{Acknowledgements}

We thank the Directors of the following herbaria for the loan of material for this study: BRI, CANB, DNA, MEL, PERTH, UNSW. Many people assisted this project through their collection of specimens, and by exchanging ideas and providing comments on these new taxa of Acacia. For this help we are very grateful to Messrs John Brock, Clyde Dunlop, Paul Munns, Lyn Craven, A. Slee, Les Pedley, Bruce Maslin, Chris Puttock and David Keith, Drs Richard Cowan and Peter Wilson, and Mrs Mary Hancock and Mrs Betty Maloney. The botanical illustrations were skilfully undertaken by Ms Marion Westmacott. Dr Lawrie Johnson provided several suggestions on the Latin. This study could not have been completed without the support of Prof. Carrick Chambers (NSW), Dr Barbara Briggs (NSW) and Mr Alex George (ABRS). The Royal Botanic Gardens and Domain Trust (Sydney) and the Australian Biological Resources Study are gratefully acknowledged for funding this project, including field work by M.D. Tindale in the Northern Territory in 1979 and 1989. The latter was carried out with the kind cooperation of the staff of the Herbarium of the Northern Territory.

\section{References}

Cowan, R.S. \& Maslin, B.R. (1990) Acacia miscellany 2. Species related to A. deltoidea (Leguminosae: Mimosoideae: Section Plurinerves) from Western Australia. Nuytsia 7: 201-208.

Lee, A.T. (1948) The genus Swainsona. Contributions from the New South Wales National Herbarium 1: 131-271.

Pedley, L. (1987) Racosperma deltoideum (Cunn. ex G. Don) Pedley (Leguminosae: Mimosoideae) and related species in northern Australia. Austrobaileya 2: 314-320.

Tindale, M.D. (1978) Notes on Australian taxa of Acacia No. 5. Telopea 1: 371-386.

Tindale, M.D. (1980) Notes on Australian taxa of Acacia No. 7. Telopea 2: 113-125.

Manuscript received 22 November 1991

Manuscript accepted 26 March 1992 